\title{
Creating identities in the mortuary arena of the Greek Final Neolithic: a contextual definition of practices in Central and Southern Greece
}

\author{
Katerina Psimogiannou \\ Agios Konstantinos, Lokris, GR \\ katerina_psimogiannou@yahoo.gr
}

\begin{abstract}
It is generally accepted that the Greek Final Neolithic witnessed many social and economic changes. However, few studies have explored the archaeological material of the period in a systematic and fully contextual manner. After analysing new material from a rescue excavation at Proskynas in east Lokris, central Greece, in combination with previous evidence, it is clear that most of our knowledge has come from the funerary domain, where acts of consumption and display of material culture took place. These included the deposition of artefacts in a mortuary context and in pits dug into the bedrock in the vicinity of the graves. The aim of this paper is to provide a contextual approach of the social and mortuary practices of the period in central and southern Greece and discuss their role to the creation of cultural identities. It is also suggested that these collective acts that occur primarily within the funerary domain may also imply a shift of interest from the domestic to the mortuary arena, which emerges as a new place for social negotiation at the end of the Neolithic period.
\end{abstract}

IZVLEČEK - Splošno sprejeto je mnenje, da je v grškem končnem neolitiku prišlo do mnogih socialnih in ekonomskih sprememb. Le malo je študij, ki so se sistematično ukvarjale z arheološkim materialom in konteksti tega obdobja. Po analiziranju novega materiala z zaščitnih izkopavanj na najdišču Proskynas v vzhodnem Lokrisu, osrednja Grčija, in prejšnjih podatkih, je postalo jasno, da je naše vedenje večinoma povezano s pogrebnimi praksami, pojedinami in razkazovanjem materialne kulture. To vključuje tudi polaganje predmetov v grobne kontekste in jame, vkopane v skalno podlago v bližini grobov. V članku se ukvarjamo s socialnimi konteksti in pogrebnimi praksami v tem obdobju v srednji in južni Grčiji in analiziramo njihovo vlogo pri oblikovanju kulturnih identitet. Ocenjujemo, da so skupinska dejanja, ki so se dogajala v okviru pogrebnih praks, morda pomenila odmik od hiše h grobišču kot novem prostoru socialnih delovanj in pogajanj ob koncu neolitskega obdobja.

KEY WORDS - Final Neolithic; central and southern Greece; mortuary practices; pits; structured deposition; identity

\section{Introduction: the chronological background}

For several decades in Greek prehistory, a division of the Neolithic and Bronze Age in units of three for each particular period has been established1. The Neolithic has been divided into Early, Middle and Late and each of them, except for the last, was further divided into three parts, a system mostly utilised in Thessaly and the Peloponnese (Demoule,
Perlès 1993.398). Nevertheless, the efforts to group Neolithic cultures according to this tripartite chronological terminology do not seem to depict the reality successfully.

In south-eastern Europe, the millennium that starts at the mid $5^{\text {th }}$ millennium $\mathrm{BC}$ forms a period that

1 Wace and Blegen established in 1916-18 a relative chronological system for the Bronze Age on the Greek Mainland, calling it 'Helladic', in parallel to Cretan finds, called 'Minoan'. 
does not fit into the classic three-age system, and how it is approached implicitly determines the terminology employed (Bankoff, Winter 1990). In Greece, the later stages of the Neolithic spanning from $4500 \mathrm{BC}$ to $3500 / 3300 \mathrm{BC}$ or $3100 \mathrm{BC}$ (Andreou et al. 1996.538; Johnson 1999; Tomkins 2009.127) are rendered by the German archaeologists (in Thessaly) as belonging to a Chalcolithic period (Wace, Thompson 1912; Alram-Stern 1996; 2003), according to the terminology in Asia Minor and the northern Balkan peninsula, while in recent decades, especially for southern Greece, the term 'Final Neolithic' has been used (Phelps 2004.103). The term 'Final Neolithic' (hereafter FN) as used in this paper, was suggested by Colin Renfrew (1972.68-80) to define the character of a cultural horizon of the last Neolithic phases, characterised by relatively homogeneous pottery assemblages in the areas of Attica, Euboea and the north-western Cyclades (the so-called 'AtticaKephala culture', named after the excavation at Kephala (Fig. 15.14) on the island of Kea). On the other hand, some scholars (Zachos 1987.3-5; Coleman $1992 a$ ) prefer the term 'Late Neolithic II', because this period lasted well over 1000 years, covering most of the Late Neolithic.

What is generally accepted, however, is that this extremely long period witnessed many social and economic changes, such as intensive exploitation of the marginal land of the Greek landscape (Runnels, van Andel 1987; Demoule, Perlès 1993; Watrous 1994; Cavanagh 2004; Tomkins 2008; 2009), the introduction of metals and metallurgy and wide-range exchange links (van Andel, Runnels 1988; Perlès 1992.154-155; Broodbank 2000.163). In terms of pottery, it is characterised by an increase in coarse pottery and vessels fired at very low temperatures, often bearing traces of burning on their surface (Demoule, Perlès 1993.401; Vitelli 1999.65; Cavanagh 2007). It is argued that all these new vessels, including a variety of pithoi, jars and deep bowls, would have served new uses, associated with practices of storing and processing food (Halstead 1995.17; Vitelli 1995.58).

Most of our archaeological knowledge of this period in southern Greece was based on the excavation of the Kephala cemetery on Kea (Coleman 1977) and the cemetery of Tharrounia (Fig. 15.15) on the island of Euboea (Sampson 1993), where small built graves were investigated. The rest of our information comprised preliminary reports on material from excavations both at open air sites and in caves of the central and southern Greek mainland and the is- lands, such as that from the Acropolis North slope (Immerwahr 1971), Eutresis (Group II) in Boeotia (Caskey, Caskey 1960), Lerna (Caskey 1957; 1958; 1959; 1960) and the Franchthi cave in the Argolid (Vitelli 1999), the Zas cave on Naxos (Zachos 1999) and many other sites, such as those included in Phelps' study of the Neolithic pottery sequence in the Peloponnese (Phelps 1975; 2004). The evidence for the Final Neolithic has improved notably through intensive surface surveys (van Andel et al. 1986; Runnels, van Andel 1987; Wells et al. 1990; Runnels et al. 1995; Cavanagh et al. 2002), while new excavated domestic remains include the fortified sites at Zagani in Attica (Steinhauer 2001) and Strophylas on Andros (Televantou 2008), where occupation seems to continue into the Early Bronze Age (but the material is currently under study).

However, since most of the traditional archaeological research in Greece (Tomkins 2008.21) has so far been concerned mainly with describing the pottery style and cultural relations with other regions, few studies of FN archaeological material have explored the relationship between the elements of the material culture of the period in a systematic, focused and fully contextual manner. The recent research at the site at Proskynas in the province of Phthiotis in central Greece, in combination with all previous evidence, proved to be fundamental to a better understanding of the social and mortuary practices of the period. At the same time, it gave rise to further questions and archaeological discussion.

\section{The site at Proskynas, central Greece: a case study}

The site at Proskynas (Fig. 1) next to the modern village of that name is located on a low hill of soft limestone in the area of east Lokris in central Greece. The site overlooks a small, fertile valley, while the Euboean Gulf is situated $3 \mathrm{~km}$ to the north. The wooded foothills of Mt. Chlomon, dividing east Lokris from neighbouring Boeotia, rise immediately to the south.

The area of east Lokris (Fig. 1), a narrow, coastal zone and the south-eastern district of the province (nomos) of Phthiotis, has been a field of interest for archaeologists since the early $20^{\text {th }}$ century. Many rescue and systematic excavations of Bronze Age settlements and cemeteries have enriched our knowledge about the whole period (Dakoronia et al. 2002). Nevertheless, when the investigation of the Neolithic period is concerned, very little has been 


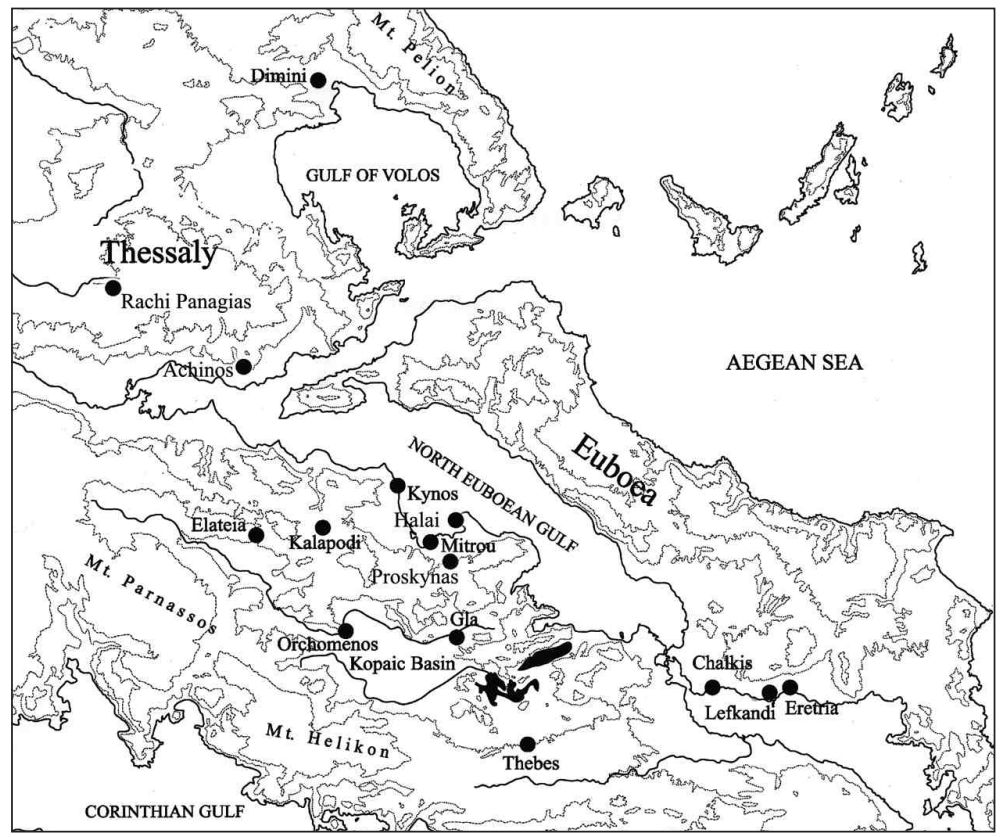

Fig. 1. Map of east Lokris indicating Proskynas and other prehistoric sites (adapted from Van de Moortel and Zahou 2006.Fig. 1). lithic, Early Helladic II, Middle Helladic and Late Helladic periods. Unfortunately, the site had gone unnoticed when the initial construction of the main national road destroyed a large part of it in 1962.

The Final Neolithic remains lay immediately above bedrock on the flat surface of the hill and almost at its centre. On the same area, after a period of abandonment, a settlement was founded in the early Early Helladic II period (hereafter $\mathrm{EH})(\mathrm{Za}$ hou 2004; 2009), while during the Middle Helladic and Late Helladic period, settlement relocated to the west side (Zahou 2009.10-13). This kind of human activity and horizontal shifting on the hill makes Proskynas a non-tell site, in the sense that the area was not as densely occupied done in this region. A significant site close to the coast of the Gulf of Euboea has been located at Theologos (ancient Halai) (Fig. 1). The earlier excavations were carried out from 1911 to 1935 by Hetty Goldmann and Alice Walker Cosmopoulos (Goldmann 1940), while John Coleman's fieldwork in the past 15 years has revealed deposits dating back to the Early and Middle Neolithic (Coleman 1992b). Other important sites that usually appear as mounds (magoules) have been located in northern Phthiotis as that of the tells (magoules), thus without intensive and extensive rebuilding on the same parts of the hill. The stratigraphy and spatial practices at the site indicate that occupation between the different periods was interrupted for some time (Zahou, Psimogiannou forthcoming).

The earliest phase of occupation at Proskynas, i.e. the FN, is represented only by burials and pits dug into the soft bedrock. The Neolithic deposit was a and in the western part of Lokris (Alram-Stern 1996.305311), such as at Elateia (Fig. 1). However, archaeological investigation here was limited and its unpublished material is known through Weinberg's (1962) preliminary report.

\section{The excavation and occu- pation phases}

The rescue excavation at Proskynas (Fig. 2), covering approximately $1500 \mathrm{~m}^{2}$ and undertaken by the $14^{\text {th }}$ Ephorate of Prehistoric and Classical Antiquities under the direction of Eleni Zahou, before the extension of the main national road, investigated four phases of occupation dating respectively to the Final Neo-

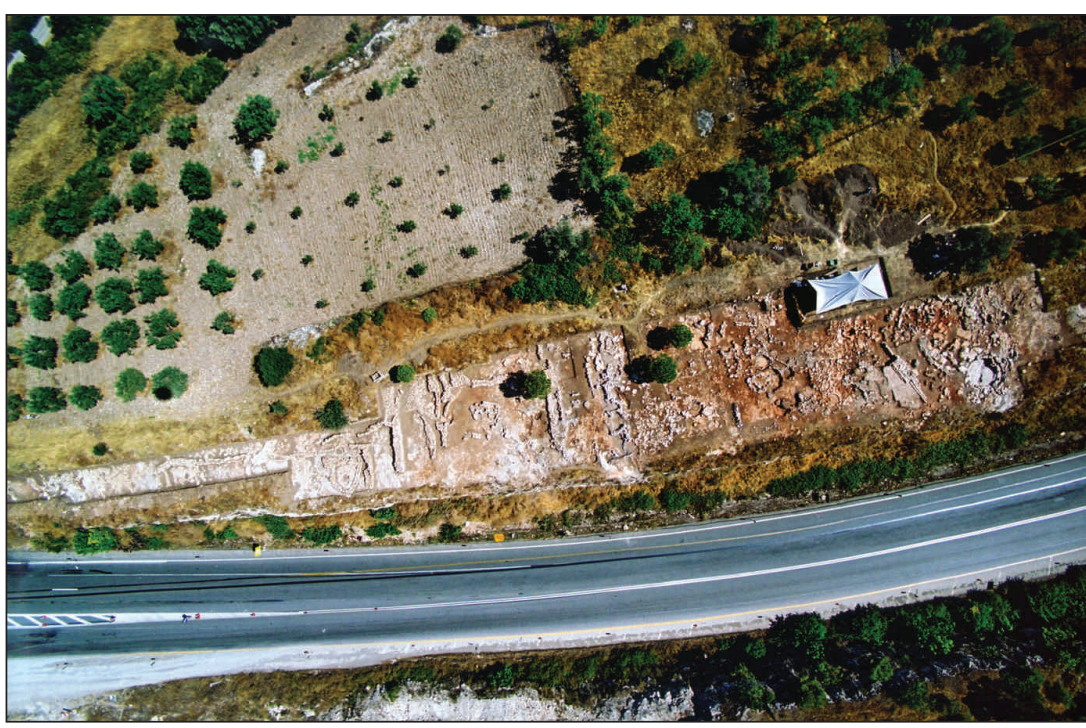

Fig. 2. The rescue excavation at Proskynas, east Lokris (after Zahou 2009. Fig. 2.2). All the photos and the drawing plan of the excavation are from the archives of the 14th Ephorate of Prehistoric and Classical Antiquities, Lamia, Greece. The images were afterwards processed by the photographers Ilias Kouvelis and George Maris. 
thin, undisturbed stratum 2 , only $20 \mathrm{~cm}$ thick, lying immediately above natural bedrock and containing pottery of different wares, lithics, shells and animal bones. The Final Neolithic in the area of Lokris was until then unknown 3 . In northern Phthiotis, Rachi Panagias (Fig. 1), a tell-prehistoric-site adjacent to the Lake Domokos area has shown occupation levels from the $4^{\text {th }}$ millennium $\mathrm{BC}$ according to the radiocarbon dates and the characteristic pottery ware. Examples include bowls of the socalled 'Bratislava type', decorated with patterns of spirals and incised lines and triangles (Zahou 2002).

\section{The Final Neolithic archaeolog- ical evidence: the burial area}

The Final Neolithic archaeological evidence at Proskynas consists of a burial area, where seven burials and a series of pits were investigated. They extend over the hill on the EW axis. The EH buildings and constructions followed the same orientation and were founded exactly above the FN burial site (Fig. 3).

In the southern part of the excavated area and across the national road, eight pits developed in a row (Fig. 3.pits 16-20, 8-10). The pits (Fig. 4a-b), round or ovoid in shape, with a maximum depth of $0.50 \mathrm{~m}$ and with a diameter up to $1.50 \mathrm{~m}$, were filled with burnt cultural material, such as sherds or large parts of coarse open vessels, bones, shells and obsidian or flint blades. Some pits were coated with clay and after being filled, were sealed with stones. Nearby, and to the north, a number of round postholes, $0.30 \mathrm{~m}$ in diameter were found which seem to have

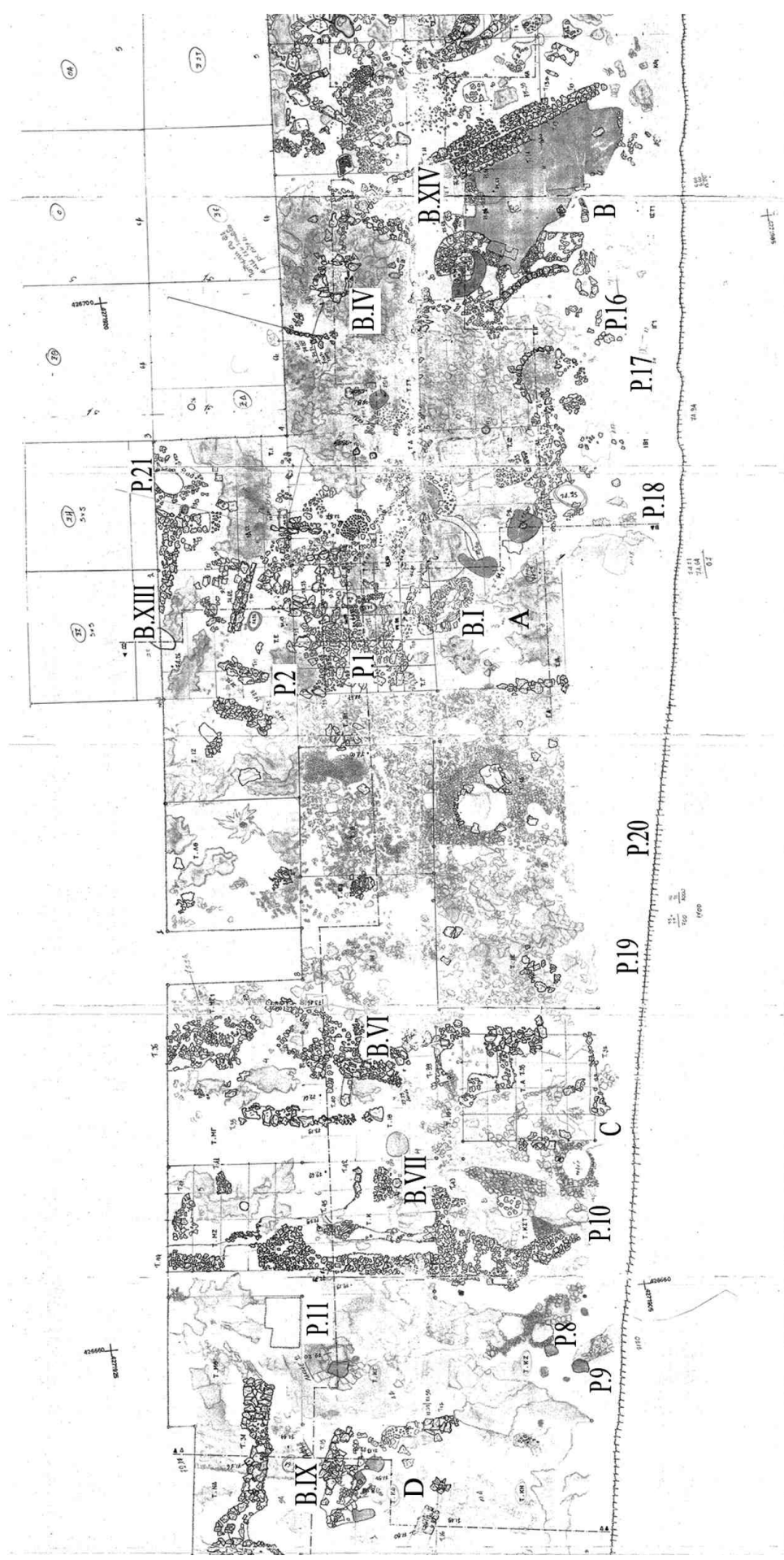

Fig. 3. Location of the Final Neolithic pits and burials under the structures of the Early Helladic II settlement (P. stands for pit, $B$. for burial; A, B, C, D: EH buildings).

2 The use of bedrock for FN activities is witnessed in many cases in the Peloponnese and central Greece (see discussion in the text below). As was observed, the FN layer in Peloponnesian sites is mostly described as a thin, dark-red or brown stratum lying directly above bedrock (e.g., Aspis Argos, see Touchais 1980; Alram-Stern 1998.25; Vitelli 1999.99). This was also the case at Karystos on Euboea (Keller 1982.12), several sites in Attica (e.g., Koropi, Merenda, Thorikos, see Spitaels 1982; Alram-Stern 1996. 216-218; Kakavogianni et al. 2009), on Aigina Kolonna (Felten, Hiller 1996), on the Cyclades (e.g., Grotta Naxos, Hadjianastasiou 1988.11-12; Agia Eirini Kea, Wilson 1999) and on Crete (Nowicki 2008.205).

3 Final Neolithic pottery has recently been identified (both pers. exam.) at the sites on the islet of Mitrou, Tragana (Fig. 1, see Van de Moortel, Zahou 2006) and Kynos, Livanates (Fig. 1, see Dakoronia et al. 2002.41-48). 

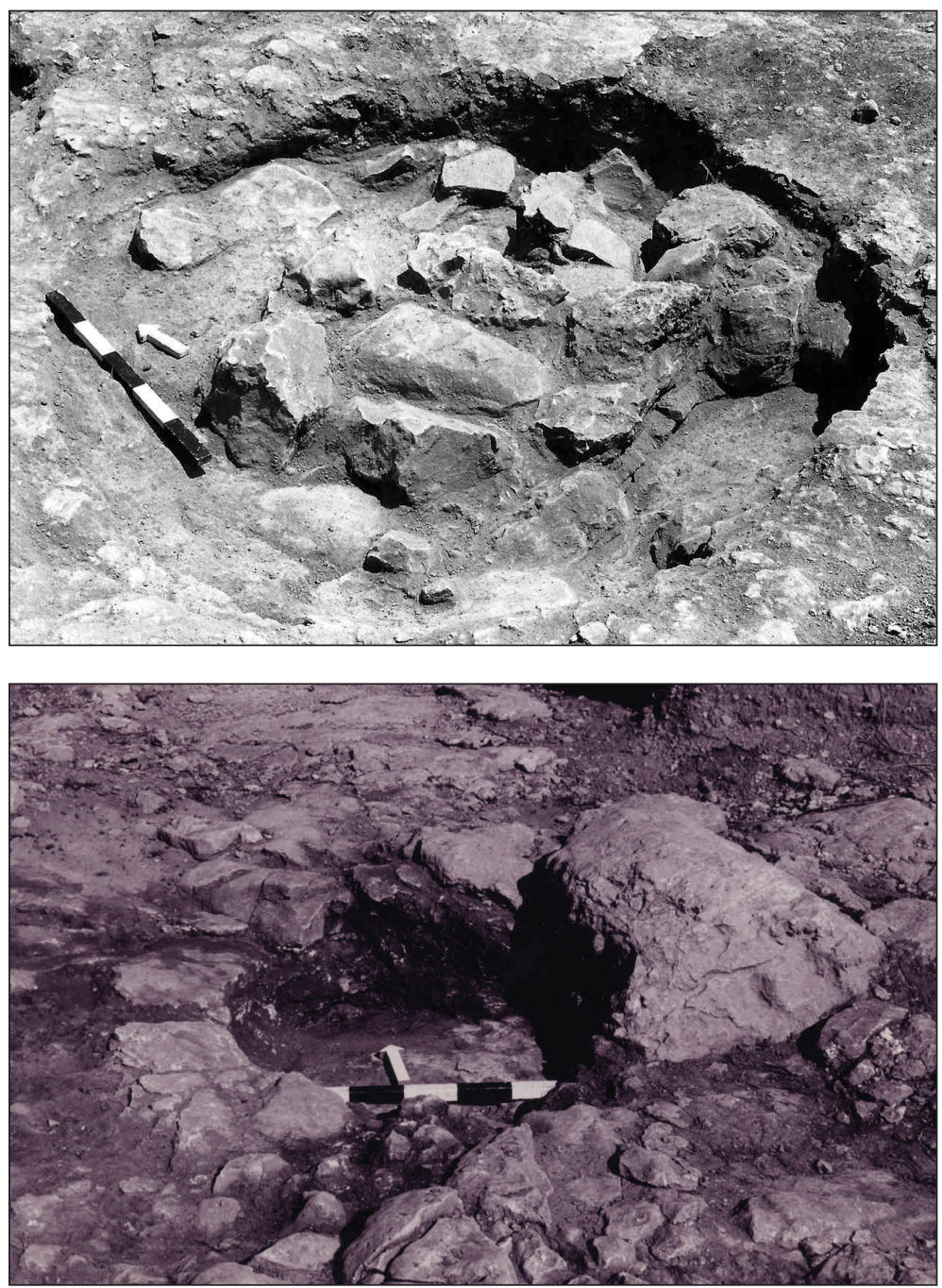

Fig. 4a-b. Final Neolithic pits.

comprised part of a wooden ditch, given their position in a row and $\mathrm{E}-\mathrm{W}$ orientation.

Farther to the north of these posts (Fig. 3), five adult men and two children, according to the osteological analysis, were buried. The mortuary practices are characterised by variability, since all the adults were placed in simple pit graves, cut also into the bedrock, while the two children were treated differently.
The pit graves were ovoid and shallow, containing only single burials (Fig. 3.burials IX, VI, VII, XIV, XIII). The skeletons of the adults 4 were found in situ and in a contracted position (Fig. 5a-b) without offerings or fixed orientation. Adjacent to some of these graves, pits containing cultural debris like those found in the southern part of the hill were also investigated (Fig. 3.pits 11, 21).

In contrast, the burnt human remains of a 15-year-old juvenile had been placed in a burial pot (Fig. 6) that was found in the same funerary area (Fig. 3.burial I), while the second child had been deposited in a rectangular grave, dug into the bedrock, lined and covered with small flat stones (Fig. 3.burial IV; Fig. 7). We cannot be sure about the criteria that determined these choices. Whether or not other members of the Neolithic 'community' of Proskynas received a similar or different type of manipulation after death remains unknown, and the occurrence of more burials on the area of the hill that has not been excavated may be possible. Next to the burial pot, two shallow pits had been cut into the soft bedrock (Fig. 3.pits 1, 2). One contained only burnt soil, while a red-burnished pithoid jar5 (Fig. 8) was placed in the other, which was lined with stones.

The whole burial site had been sealed with small row stones $\mathbf{6}$ and every EH building was founded above a FN pit grave, after a period of abandonment (Zahou, Psimogiannou forthcoming), as can be seen in the case of Grave IX under Building Delta (Figs. 3, 9).7

4 I would like to thank Dr. Anastasia Papathanasiou at the Ephorate of Palaeoanthropology and Speleology, Athens for conducting the osteological study. The samples collected from the adult burials were submitted to the Radiocarbon Laboratory at the University of Oxford and produced radiocarbon dates in the later $5^{\text {th }}$ millennium BC (around 4400-4300 BC).

5 A large number of pithoid jars has been found above the platforms and around the graves of the cemetery at Kephala, Kea ( $\mathrm{CO}^{-}$ leman 1977.52-53) and the cemetery at Tharrounia, Euboea (Sampson 1993.233).

6 The practice of covering FN burials with a pile of stones is attested at Lerna (Vitelli 2007.122) and in the paralia of the Franchthi cave in the Argolid (Vitelli 1999.90), in the Kouveleiki cave B in Laconia (Kontaxi 1996.712), as well as at other locations (see Dousougli 1998.136-145).

7 Early Helladic domestic remains overlapping FN bedrock deposits - sometimes of a mortuary or symbolic character - have also been identified at the sites at Lerna (Caskey 1960; Vitelli 2007.122), Voidokoilia (Korres 1977; 1978), Ayios Dhimitrios (Zachos 1987), Ayia Eirini, Kea (Caskey 1972; Wilson 1999; Broodbank 2000.218), Aigina Kolonna (Felten, Hiller 1996). See more discussion in Zahou, Psimogiannou forthcoming. 
The burial area of Proskynas has yielded important ceramic (Psimogiannou 2008), faunal and lithic (Manos 2011), and molecular 8 (Veropoulidou 2011) assemblages. In terms of the pottery, a large number of sherds or partially preserved vessels were concentrated around the graves. The ceramic assemblage of the burial area is large and shows close similarities to styles found in this period in southern Greece and the Aegean, as well as the ceramic material from the pit contexts (Fig. 10).

The pottery represented comprise 'tableware', meaning pots appropriate for the consumption and presentation of food and/or drink, such as cups and bowls, but including larger vessels such as large deep bowls, wide-mouthed jars and pithoi intended to cater both for preparing or cooking food and even for some kind of storage. It is interesting to notice that the largest quantity of pottery was concentrated around the two child burials. In the vicinity of the burial pot, a particularly high concentration of vessels of matt-painted and polychrome ware, mostly cups and fruitstands, was found (Fig. 11.a,b,c). Coarse
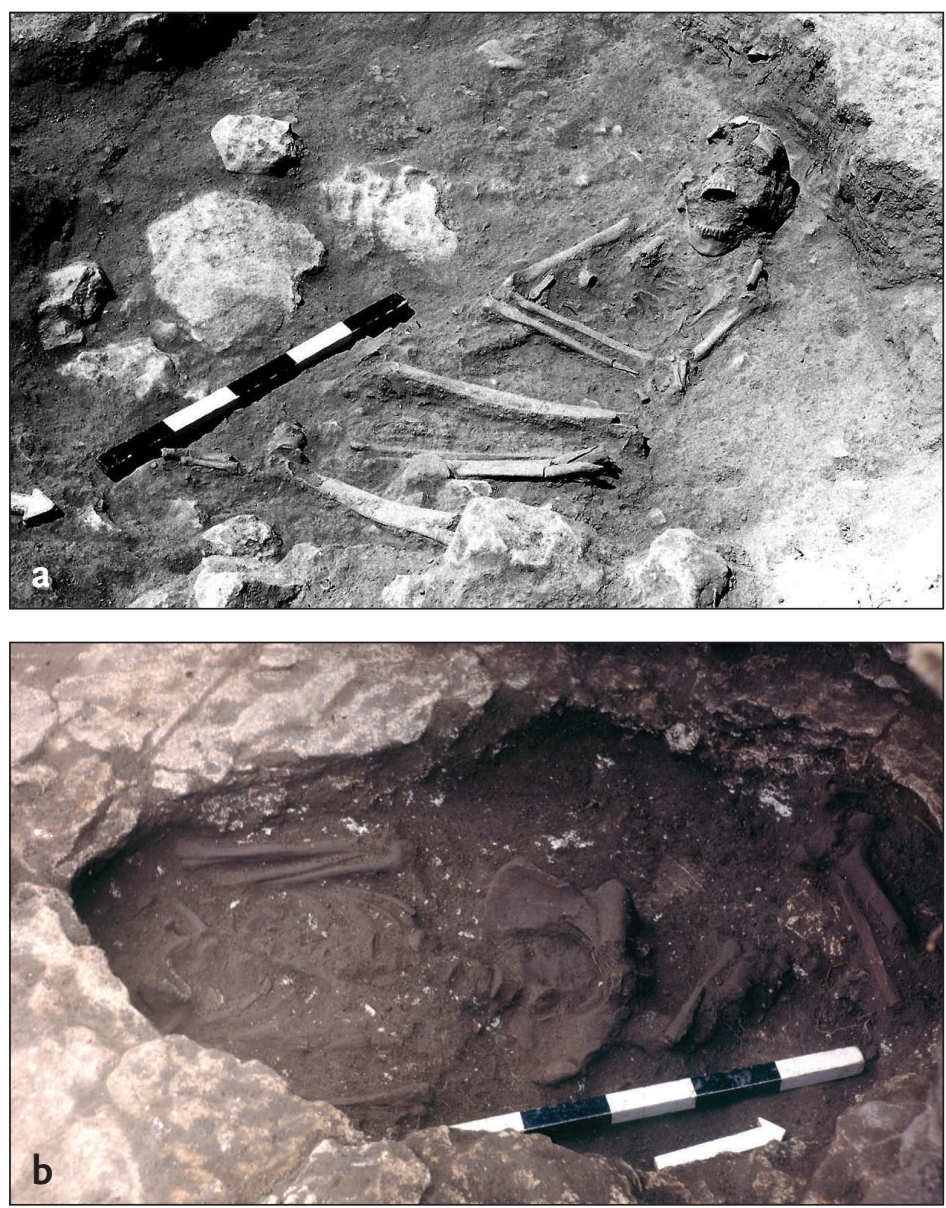

Fig. 5a-b. Pit burials; a. adult, man, 45 years old; b. adult, man, 30-35 years old. vessels, jars or deep bowls were also found nearby. More intriguing, however, is the fact that no two pots are alike, every piece is unique. The drinking vessels of the matt-painted and polychrome ware show high variability and diversity in decoration and may have been used for individual consumption and display (Pappa et al. 2004; Urem-Kotsou, Kotsakis 2007.242). Furthermore, most were found incomplete, something that raises the possibility that these objects were probably never deposited as complete items. The same practice is reported from the Alepotrypa cave, where the human remains of two children were laid on a stalagmite floor and then covered by great quantities of intentionally broken matt-painted and polychrome ware (Papathanasopoulos 1996b.176; Papathanasiou 2001; 2009).

The second child at Proskynas had not only received different mortuary treatment - different kinds of pottery ware seem to have been deposited around this grave. Most belong to coarse vessels, showing close similarities to the pottery from the cemetery at Kephala. These vessels include deep bowls (Fig. 12), jars and baking pans (Fig. 13), some bearing redcrusted (Fig. 14) and pattern-burnished decoration, features with a broad distribution throughout the Aegean during this period. One marble figurine of the schematic type9 had been placed adjacent to the second child's grave, while a lithic pendant had been placed inside.

\section{Final Neolithic social and mortuary practices in context}

\section{Looking back: a review of the evidence}

The archaeological analysis of the FN material at Proskynas provided evidence to support an interesting discussion of the social and mortuary practices of the period (Psimogiannou 2008.104-114). Examination of both old and new archaeological evidence in central Greece, in the Peloponnese and the

8 According to Veropoulidou (2011), the shells collected from the pits and burial area were the result of food processing. 


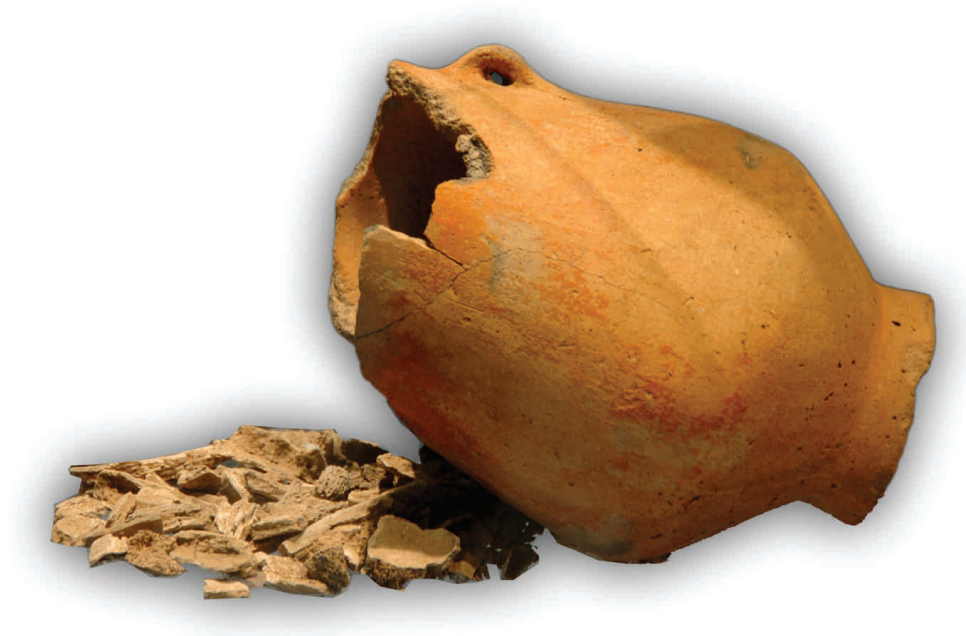

Fig. 6. Burial pot with associated skeletal remains of a 15-year-old child. All the photos of the pottery are by the author.

Aegean islands has indicated that the digging of pits was a common and widespread social practice in the Greek Final Neolithic, since specific cultural elements deposited in pits have been found in a surprisingly wide range of sites (Fig. 15). These pits are described as open-air pits not associated with any architectural or structural remains, filled with burnt material and then sealed with stones. The fact that they were dug into the pure bedrock, on hills of limestone with notable visibility $\mathbf{1 0}$, but in most cases without previous Neolithic occupation levels, seems to have been a deliberate choice.

This was the case (see Fig. 15) in Eutresis Boeotia (Caskey, Caskey 1960.129-137), in the Acropolis North slope (Immerwahr 1971.3, the so-called Neolithic 'wells') and especially at many sites in the Peloponnese, such as in Prosymna (Blegen 1937. 23-29) and Halieis in the Argolid (Pullen 2000), Tsoungiza in Corinthia (Pullen 1990. 33; 2011), as well as Ayios Dhimitrios in Elis (Zachos 1987.4-48), Nichoria in Messinia (Howell 1992) and Voidokoilia in Pylos (Korres 1977; 1978; 1979). In the 1960 s, various isolated pits in the bedrock were explored while examining the Hellenistic settlement at Kastro Tiga- ni on Samos (Felsch 1988). Similar FN 'wells' filled with cultural debris have also been found recently on east (Manteli 1992) and central Crete (Pylarinou, Vasilakis 2010). A deposit very much like these was unearthed at the site at Ayia Eirini on Kea (Caskey 1972.360-362; Coleman 1977.99). Further north, at Rachmani in Thessaly, some rescue excavations on the western edges of the tell that became synonymous with the Chalcolithic period of Thessaly, since the archaeological research of Wace and Thompon (1912), revealed pits dated to the FN filled with sherds, animal and human bones, lithics and shells (Toufexis 1997). Similar pits have been investigated recently on a hill at Achinos in the eastern part of Phthiotis (Fig. 1) near the Maliakos gulf (pers. exam.).

Most frequently, however, these pits are reported adjacent to pit graves of the same period, also cut into soft bedrock (Fig. 15), such as at Proskynas, in the Athenian Agora and in the Acropolis South slope (Immerwahr 1971; 1982; Dousougli 1998.137), at Thebes (Tsota 2009), Lerna (Caskey 1958.13-137; 1959.205; Vitelli 2007.118-122) and Franchthi (paralia) in the Argolid (Vitelli 1999.87-91), and in the Alepotrypa cave (Papathanasopoulos 1971). The same probably holds for the site at Galene in Thessaly (Toufexis 1997), where a number of deep and

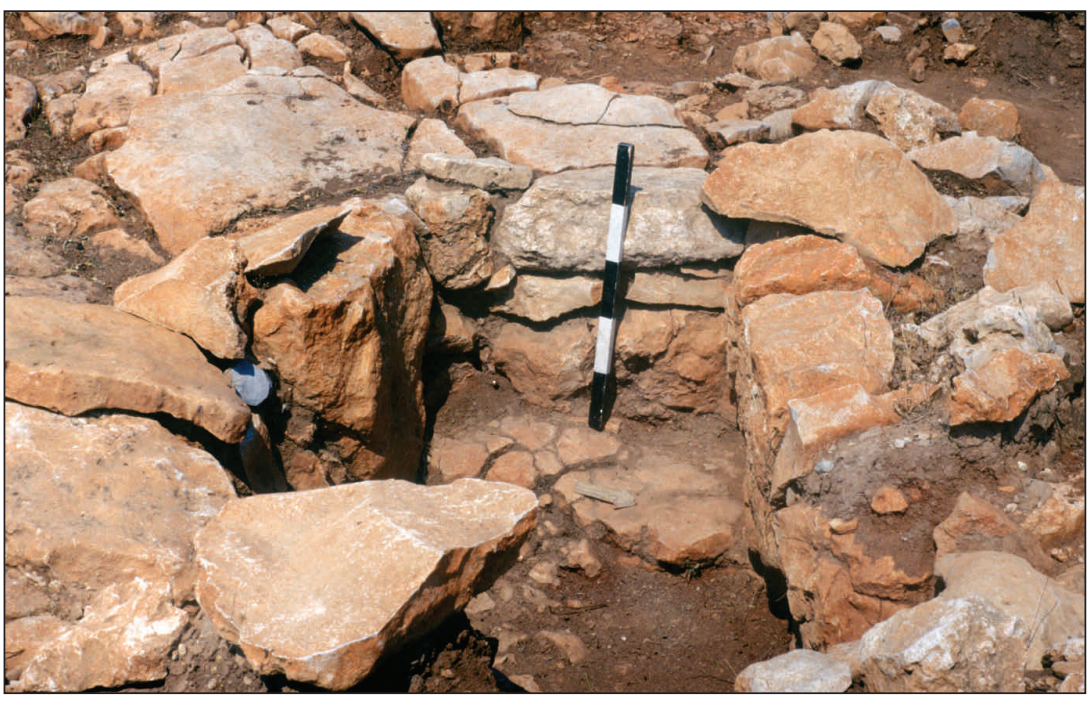

Fig. 7. Rectangular grave of a 10-year-old child, dug into the bedrock.

10 It is mentioned that the FN sites in the Peloponnese are situated above valley bottoms, overlooking the broader areas (Alram Stern 1998.75). The same holds for Proskynas. 
wide pits characterised as 'wells' and filled with cultural debris were excavated. Three burials of adults in a contracted position were clustered nearby, while another was found in a pit (Toufexis 1997. 570-571). According to a recent overview of the Neolithic evidence at Phaistos on Crete (Todaro, $D i$ Tonto 2008), the FN remains under the structures of the First Minoan Palace consist of a series of pits cut into the bedrock and related to a burial in the vicinity. 11

\section{The creation of a mortuary arena and the practice of pit-digging}

The picture that emerges from the above current evidence is the high visibility of mortuary places during the FN period (Fig. 15). Indeed, most of our knowledge of central and southern Greece comes from the funerary domain $\mathbf{1 2}$, including the already known cemeteries of Kephala and Tharrounia that comprise built tombs. Of great importance, however, is the appearance in the archaeological record of other mortuary areas $\mathbf{1 3}$, where one or more burials were deposited in pits dug into the bedrock. This similar mortuary pattern is witnessed in many locations, some of which have already been mentioned above (e.g., Proskynas, Thebes, the Athenian Agora and the Acropolis North and South slopes, Lerna, Franchthi), as well as at other sites (e.g., Aria in the Argolid (Dousougli 1998), Akraifnio, Boeotia (discussed in Dousougli 1998.139), Koutsouria in the Argolid (Protonotariou-Deilaki 1971.10), etc.; see also discussion in Dousougli 1998).

To this funerary domain, we can add the deposition of numerous burials in caves in southern Greece (e.g., Tharrounia cave on Euboea, Alepotrypa and Kouveleiki caves in Laconia, the Cave of Pan in Attica and many caves on Crete) that are usually attributed to the FN period. For example, the Alepotrypa cave has provided a concentration of various burial practices (e.g., single and multi-

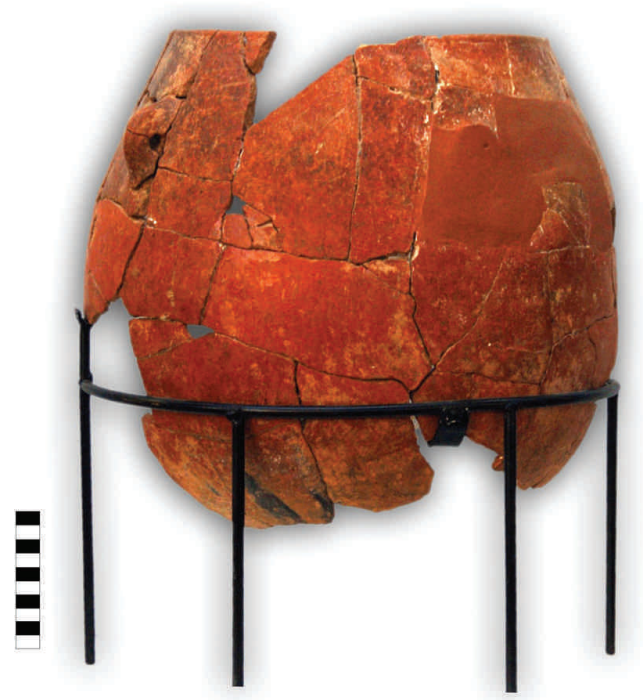

Fig. 8. Pithoid jar found near the burial pot.

ple primary inhumations, ossuaries) and more than one hundred individuals have so far been identified (Papathanasiou 2009). The presence of the material culture in the Alepotrypa cave is considered to be associated with these graves and ritual activities (Cavanagh, Mee 1998; generally for a discussion on caves see Tomkins 2009). As has been suggested (Cavanagh, Mee 1998.11), the large number of ani-

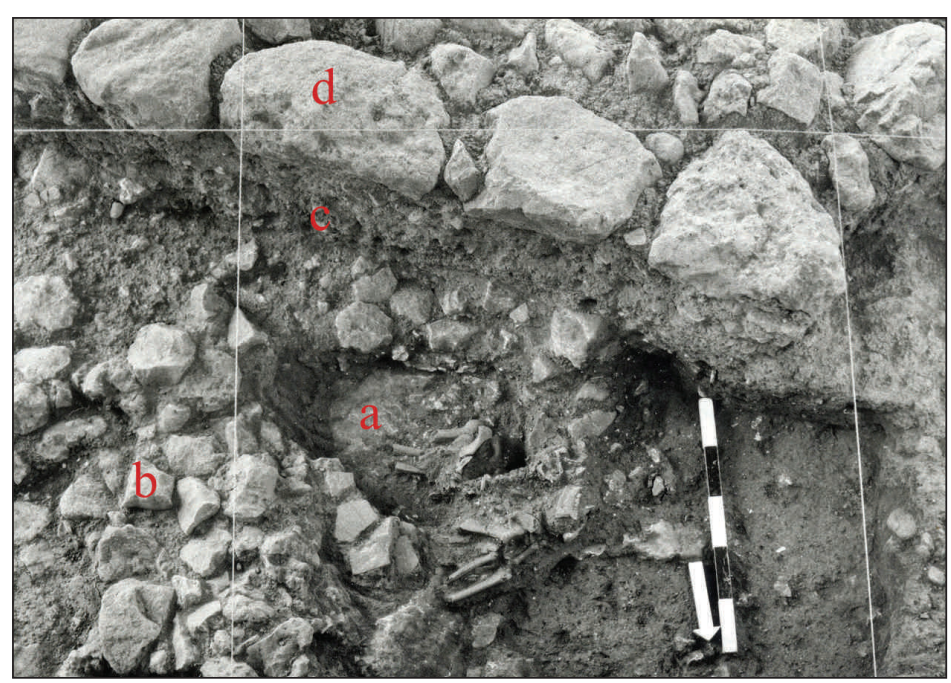

Fig. 9. a. Final Neolithic burial of an adult man, 25 years old, 4496 calBC; $b$. sealing of the burial; $c$. discontinuity; d. Early Helladic wall (House D).

11 Pits related to burials in the vicinity dated to the beginning of the EBA were also found in cemeteries on mainland Greece and the Cyclades, such as that of Tsepi, Attica (Pantelidou-Gofas 2008) and Ano Kouphonisi, Cyclades (Zapheiropoulou 2008).

12 In central and southern Greece there are less 'visible' settlement traces in contrast to burial places. Domestic or building remains, except from Srofylas and Zagani (mentioned above in the text), have also been found at Kephala, Kea and Sfakovouni in Arcadia (Alram-Stern 1996.264), and farther north in Microthebes (Adrymi-Sismani 2007) and Petromagoula (Hatziaggelakis 1984), Thessaly. Most of the material is under study.

13 The use of the term 'burial or mortuary areas' (instead of cemetery) does not exclude the possibility that more burials had been deposited. We have to keep in mind that the presence of a low number of burials may also be due to limited excavated area (e.g., Aria in the Argolid). 

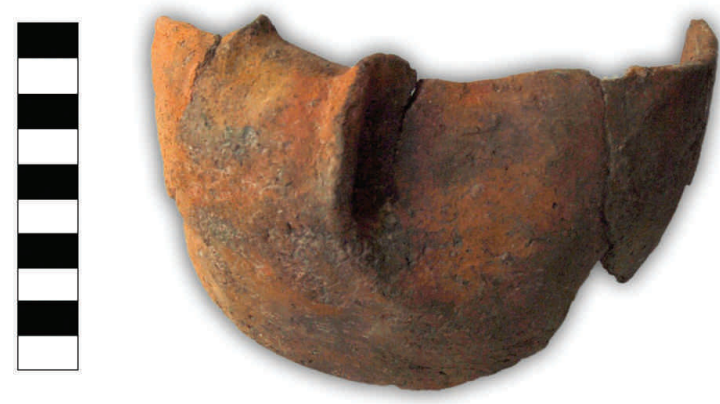

Fig. 10. Vessel from pit 10.

mal bones and pots around the burials in the cave probably indicates offerings and the consumption of food, while traces of burning imply that fire formed part of the ritual.

It seems that the presence of cultural and material assemblages in the above burial areas might suggest that important acts of consumption and display took place in the funerary domain during this period (Broodbank 2000.221-222). At Proskynas and elsewhere, vessels (not only table wares, but also larger pots) and other artefacts might have been part of special and collective acts involving mortuary rituals or feasting. It is thought that feasting, along with death and burial, is a social activity that is rich in symbolism and defines the boundaries of a group (Hayden 2001; Wright 2004.76). Of the material evidence associated with food, pottery appears to be one of the most powerful tools for investigating both the social aspects of consumption and related issues, such as social relationships and social identity (Appadurai 1986; Tomkins 2007; Urem-Kotsou, Kotsakis 2007).

Other activities, such as the deposition of material culture, either outside graves (Broodbank 2000.171) or in nearby pits, may also have been part of the mortuary practices. As already mentioned, the presence of pits filled with burnt cultural material and sealed with stones in most of these mortuary places is noteworthy. Pits are well-known excavation contexts throughout the Balkan Neolithic and pitdigging had been a widespread and common practice in Greek prehistory since the beginning of the Neolithic. For the most part, these pits have been discussed in terms of human waste disposal and thus usually referred to as 'bothroi' or 'rubbish pits' (Hutchinson 1935; Blegen 1937; Caskey, Caskey 1960.161). However, recent evidence from the European Neolithic and Neolithic of Northern Greece have led some scholars to propose that the deposi- ting of certain materials in pits rather than elsewhere must have been a calculated act (Chapman 2000; Pappa et al. 2004; Skourtopoulou 2006; Tomkins 2007.189-190; Pappa 2008), thus constituting an act of structured deposition. ${ }^{14}$

Furthermore, the fact that the contents consist for the most part of incomplete objects (e.g., non-con-
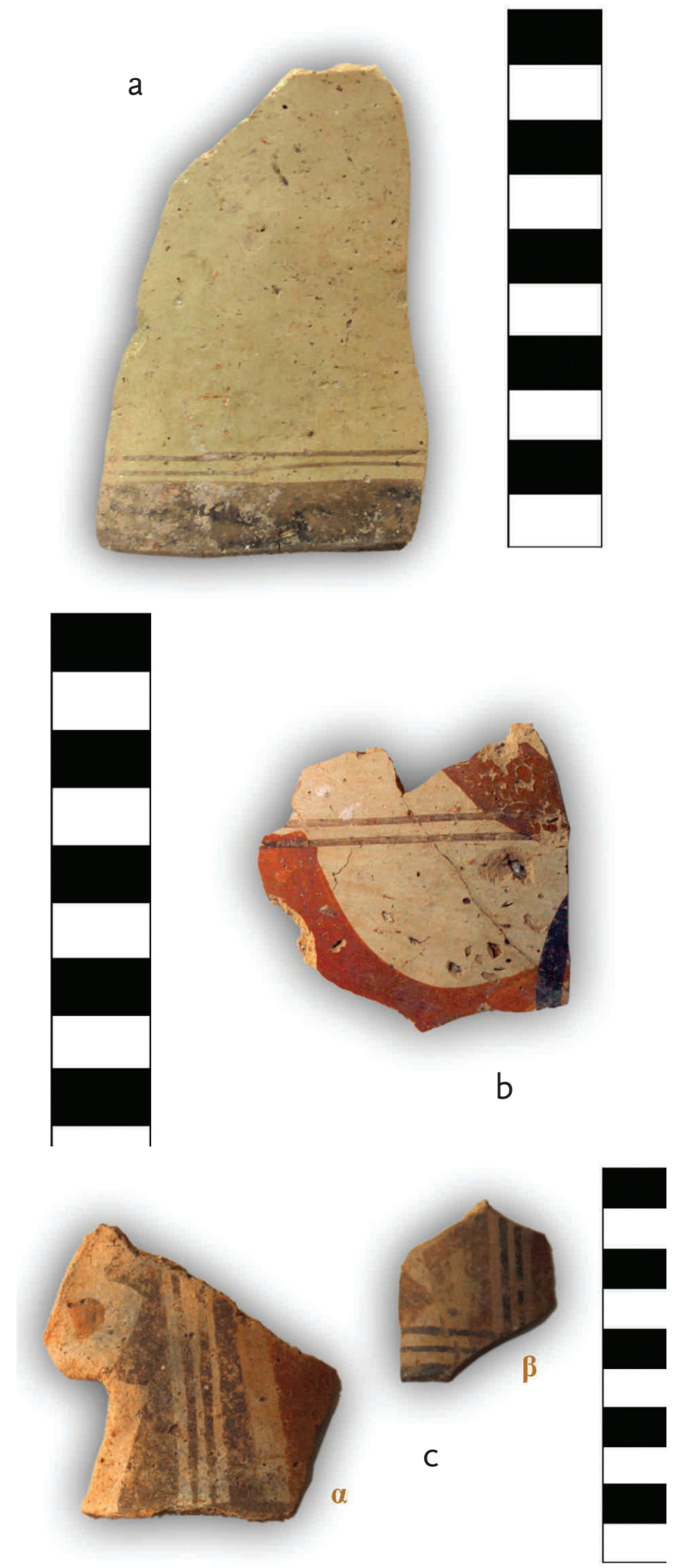

Fig. 11a-b-c. Cups and fruitstands of matt-painted and polychrome ware.

14 For more details see Chapman 2000. Also, Tasić, Tasić 2003.94-95, for a discussion of a 'cult pit' at Vinča and Sremski Karlovci, where vessels, charcoal, shells and bone fragments had been placed. 
joint sherds or large parts of vessels, fragmentary animal bones) has pointed to an interpretation of the smashing of artefacts and deposition of certain pieces in pits as having been deliberate. It is suggested that through this practice of fragmentation and deposition, the end of the life of these objects removed from circulation was accomplished (Appadurai 1986; Kopytoff 1986; Broodbank 2000.262-263; Tomkins 2009.140-142), while at the same time the life-history or 'biography' of the pit was completed through its final sealing with stones and/or fire (Chapman 2000.64; 70-73; Pappa 2008.334-336).

The repeated and widespread practice of pit-digging and their back filling indicates that the deposition of artefacts in the pits near the graves was not an act of discard, but of careful placement confirming social reproduction. The insistence on pit-digging and high density of structured deposition, as seems to be the case in the aforementioned FN sites, is a special practice probably related to a diverse set of factors. Thus, as Chapman (2000.82) has pointed out, the specially structured deposits of the pits discussed above may be integrated into a much wider set of social practices lying at the root of the FN rationality and fundamental to the creation and consolidation of social relations.

Moreover, through these acts of structured deposition and sealing with stones, a form of agency connected to the corroboration of social memory was expressed. According to Rowlands (1993), one way of creating memory is through acts such as the deposition and destruction of objects and valuables that become memories in their absence (Rowlands 1993.146; Hamilakis 1998; Bradley 2000.157). It is argued that such memory is more emphasised in the

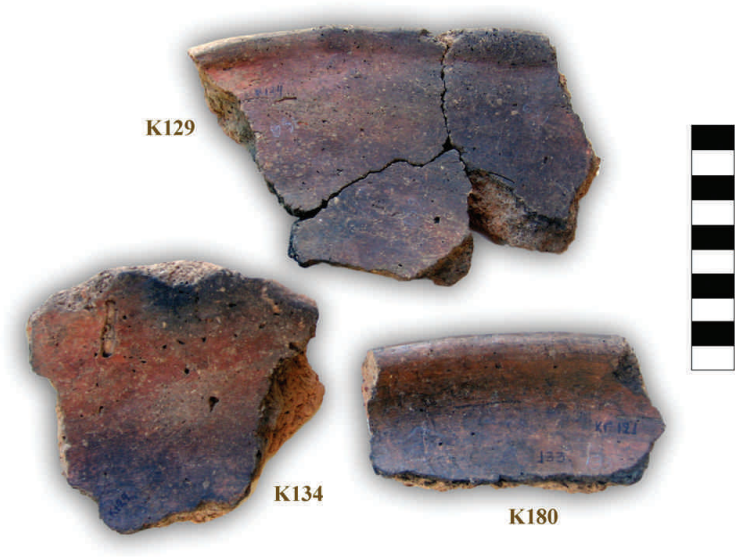

Fig. 13. Baking-pans found around the child grave.

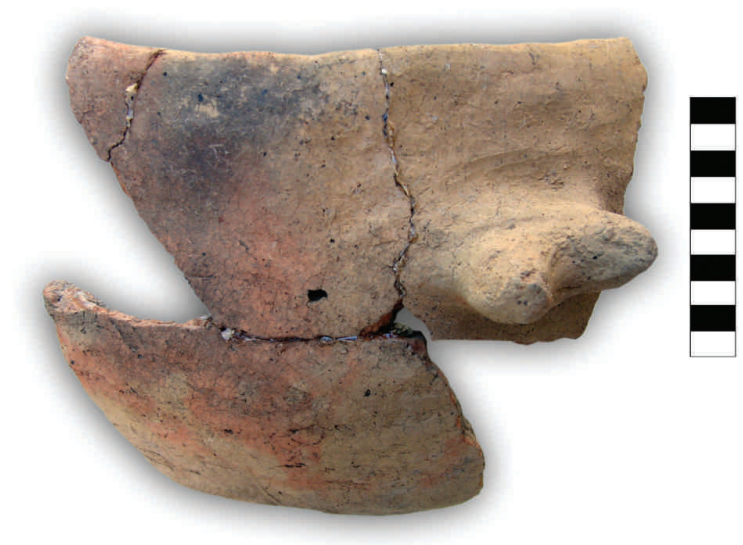

Fig. 12. Coarse vessel found around the child grave.

case of pits cut into virgin soil or bedrock, "where 'clean' material was removed and replaced by current, 'cultured' material" (Chapman 2000.64), either human artefacts or human bodies (Sofaer 2006). The FN sites are mostly 'new' sites (Darvill 1997.2) on limestone hills, the pure bedrock of which was chosen (perhaps they were already important natural places ${ }^{15}$, see Bradley 2000.107) for the deposition of the material culture and the social present of the living, a practice that endowed the sites with cultural significance, new memories and meanings (Zahou, Psimogiannou forthcoming).

I believe that the mortuary arena of the FN has to be seen as a social arena (the term is obviously borrowed from Chapman 1991; 1993; 1997.142; see

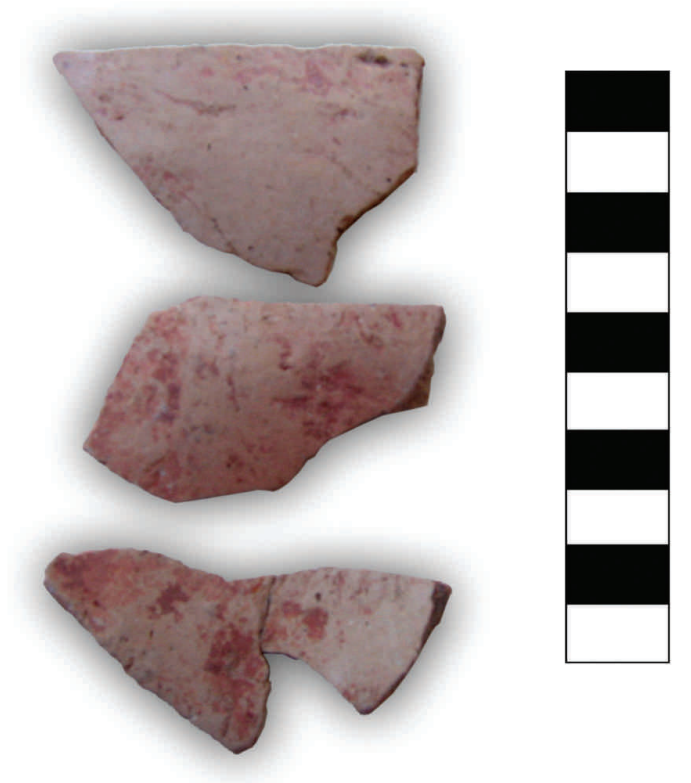

Fig. 14. Sherds of a closed vessel bearing red-crusted decoration.

15 It is not the purpose of this paper to discuss issues related to landscape uses. However, see the discussion in Tomkins 2009. 134-140, regarding the role of caves as central ritual sites for interaction during the Late and Final Neolithic periods. 
also Tomkins 2009.142-144), where - through a shared understanding of symbolic meanings in the mortuary sphere - social identities are negotiated and social integration and cohesion obtained. It has been suggested that every social practice of public ritual reinforces group identity and social memory is a technique for the control of the present, by incorporating the whole group into a common ritual associated with the past and dead ancestors (Chapman 1993.81; Parker Pearson 1993; Hamilakis 1998). It is also possible that the social memory of the ritual activity conducted on these mortuary areas endowed them with a special status that contributed to their selection as sites of the subsequent Early Helladic settlements (e.g., Proskynas, Lerna) (Zahou, Psimogiannou forthcoming). Thus, the Neolithic past was actively appropriated so as to legitimise the present (Parker Pearson 1993; Williams 1998).

\section{Discussion and Conclusions}

The picture that emerges from the current archaeological evidence discussed above, such as the widespread distribution of social and mortuary practices, and increasing spheres of

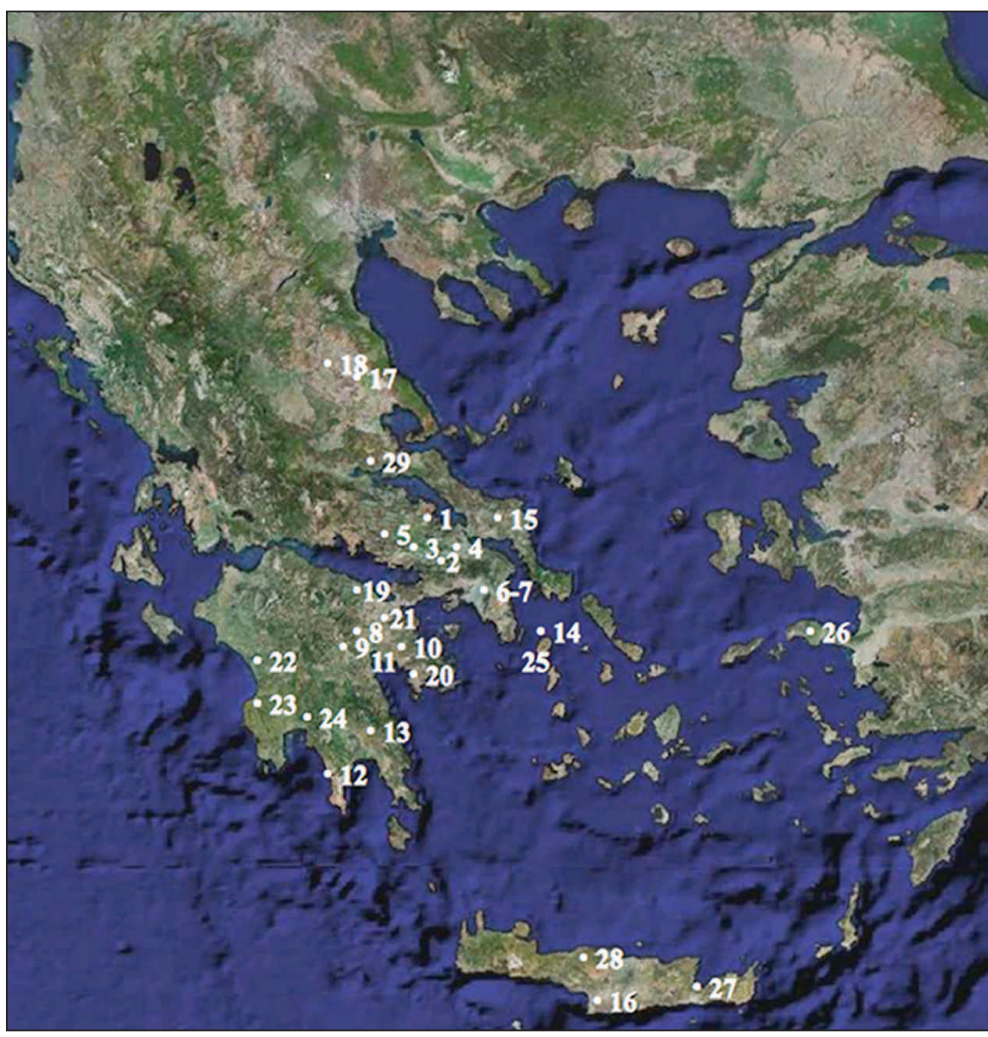

Fig. 15. Map indicating Final Neolithic mortuary and other areas discussed in the text: 1 Proskynas, Phthiotis; 2 Eutresis, Boeotia; 3 Thebes, Boeotia; 4 Akraifnio, Boeotia; 5 Chaironeia, Boeotia; 6 Acropolis North Slope, Attica; 7 Athenian Agora, Attica; 8 Aria, Argolid; 9 Lerna, Argolid; 10 Franchthi, Argolid; 11 Koutsouria, Nauplio, Argolid; 12 Alepotrypa cave, Laconia; 13 Kouveleiki cave A and B, Laconia; 14 Kephala, Kea; 15 Tharrounia, Euboea; 16 Phaistos, Crete; 17 Galene, Larissa, Thessaly; 18 Rachmani, Thessaly; 19 Tsoungiza, Corinthia; 20 Halieis, Argolid; 21 Prosymna, Argolid; 22 Ayios Dhimitrios, Elis; 23 Voidokoilia, Messinia; 24 Nichoria, Messinia; 25 Ayia Eirini, Kea; 26 Kastro Tigani, Samos; 27 Kastelli, east Crete; 28 Gazi, central Crete; 29 Achinos, Phthiotis. interaction (Broodbank 2000.156-

$170)$ represented in homogeneous pottery assemblages (Tomkins 2009.143) and other artefacts both on the Greek mainland and the islands, is of an 'internalisation' of practices and an evolving and dynamic social and cultural dialogue in which FN communities were intensively engaged. The mortuary areas mentioned above may have served as fields of social discourse for the formation and manifestation of a shared cultural identity, bearing both mainland and island characteristics (Nazou 2010). It has been suggested that collective acts of display and consumption of material culture that occur primarily within the funerary domain reflect a strong sense of communality (Tomkins 2004.56). At the same time, the individual treatment of the dead, emphasised in Proskynas and elsewhere through the presence only of single burials and the use of nonstandardised vessels or the accumulation of prestige goods, laid more emphasis on the visibility of the in- dividual and perhaps on specific members of the community (Chapman 1993; Broodbank 2000.170174). It is likely that it was a context where the identity of a large group of people was being formed and where the inclusion or exclusion of certain individuals was negotiated.

Some scholars have suggested with respect to similar cases (Hodder 1990.70-99; Chapman 1991.157; 1994.82-84) that the legitimisation of the mortuary arena as a context for social action may also imply a shift of interest from the domestic to the mortuary arena. In this respect, and taking into account the whole archaeological evidence so far regarding the FN in southern Greece, including the 'low visibility' of domestic remains, it is possible that an entirely new social arena was being created at the end of the Neolithic for the expression of social messages related to continuity, ancestors and the living (Chap- 
man 1991.160), messages that probably had previously been negotiated and visualised through the presence of the 'oikos' and the predominance of tells (magoules) on the Neolithic landscape (Chapman 1994; Kotsakis 1999; Nanoglou 2001; 2008). This broad dispersal throughout the Aegean, manifested in the aforementioned FN practices and probably removed from restricted and communally-held values and beliefs, defined, consolidated and reproduced in earlier times through the repeated materiality of the 'house' (Tomkins 2004.53-57; Nanoglou 2008.150154), may imply that an opening up to the world was also being established and a new, broader cognitive map of social relationships, acting as a unifying web of identity, was being formed (Wright 2004.6676 , for a similar discussion).

It has been argued that mortuary rituals were used as acts of display that contributed to the establishment of complex genealogical systems (Barrett 1990). The changing social strategies from the end of the Neolithic to the Early Bronze Age and the development of a social complexity have been discussed and explored in various ways and fields (Renfrew 1972; Halstead 1989; 1994; 1995; Nakou 1995; Broodbank 2000; Tomkins 2004). The relationships that the living created with the dead, but also the differences that were created between the dead (Parker Pearson 1993.227) and the way they were expressed and (re)negotiated by the living, may be indicative of a fundamental realignment and reorganisation of human relations. Of course, there are still several issues to be resolved before we can proceed further with the reconstruction of the mechanisms and details of the process that led to subsequent inequalities. Many of these details are still lacking from the archaeological record, or perhaps we have not yet been able to 'read' them, since (as always happens) they are well-concealed in every aspect of the social life, material culture and human choices that developed throughout this long-lasting period preceding the Bronze Age.

\section{ACKNOWLEDGEMENTS}

I am grateful to Dr. Eleni Zahou for continuous discussion, support and encouragement during all these years. I would like also to thank Prof. Mihael Budja for inviting me to contribute to this volume. Part of this paper was submitted as an MA thesis at the University of Thessaloniki, Greece in 2009. The responsibility for all views and errors of judgment in this study are mine alone.

\section{References}

Adrymi-Sismani V. 2007. Le site chalkolithique de Microthèbes au Carrefour du monde Égéen et des Balkans du nord. In I. Galanaki, H. Tomas, Y. Galanakis and R. Laffineur (eds.), Between the Aegean and the Baltic Seas. Prehistory Across Borders. Proceedings of the International Conference, Bronze and Early Iron Age Interconnections and Contemporary Developments between the Aegean and the Regions of the Balkan Peninsula, Central and Northern Europe. University of Zagreb, 11-14 April 2005. Aegaeum 27. Universitè de Liège, Histoire de l'art et archéologie de la Grèce antique, University of Texas at Austin, Liège and Austin: 73-79.

Alram-Stern E. 1996. Die Ägäishe Frühzeit, 2. Serie Forschungsbericht 1975-1993, 1. Band Das Neolithikum in Griechenland mit Ausnahme von Kreta und Zypern. Verlag der Österreichischen Academie der Wissenschaften. Wien.

1998. Aigeira-Achaia and the settlement pattern on the Peloponnese in the Final Neolithic and EH I. In The Prehistoric research in Greece and its Perspectives:
Theoretical and Methodological Considerations, Thessaloniki-Kastoria, 26-28 November 1998. University Studio Press, Thessaloniki: 21-28.

2003. The acropolis of Aigeira before the Mycenean settlement. In M. Bietak (ed.), The synchronization of civilizations in the Eastern Mediterranean in the $2^{\text {nd }}$ Millennium B.C. Proceedings of the SGEM 2000Euroconference Haindorf, 2nd-7th May 2001. Verlag der Österreichischen Academie der Wissenschaften. Denkschriften der Gesamtacademie 29, Vienna: $437-$ 454 .

Anderson-Whymark H., Thomas J. 2012. Regional Perspectives on Neolithic Pit Deposition: Beyond the Mundane. Neolithic Studies Group Seminar Papers 12. Oxbow books. Oxford and Oakville.

Andreou S., Fotiadis M. and Kotsakis K. 1996. Review of Aegean prehistory V: The Neolithic and Bronze Age of northern Greece. American Journal of Archaeology 100: 537-597. 
Appadurai A. 1986. Introduction: commodities and the politics of value. In A. Appadurai (ed.), The social life of things: commodities in cultural perspective. Cambridge University Press, Cambridge: 3-63.

Bankoff H. A., Winter F. A. 1990. The later Aeneolithic in Southeastern Europe. American Journal of Archaeology 94: 175-191.

Barrett J. C. 1990. The monumentality of death: the character of Early Bronze Age mortuary mounds in southern Britain. World Archaeology 22(2): 179-189.

Blegen C. W. 1937. Prosymna. The Helladic settlement preceding the Argive Heraeum. Cambridge University Press. Cambridge.

Bradley R. 2000. An Archaeology of Natural Places. Routledge. London.

Broodbank C. 2000. An island archaeology of the early Cyclades. Cambridge University Press. Cambridge.

Caskey J. L. 1957. Excavations at Lerna, 1956. Hesperia 26(2): 142-162.

1958. Excavations at Lerna, 1957. Hesperia 27(2): 125-144.

1959. Activities at Lerna, 1958-1959. Hesperia 28 (3): 203-207.

1960. The Early Helladic Period in the Argolid. Hesperia 29(3): 285-303.

1972. Investigations in Keos. Part II: a conspectus of the pottery. Hesperia 41: 357-401.

Caskey J. L., Caskey E. G. 1960. The earliest settlement at Eutresis supplementary excavations, 1958. Hesperia 29 (2): $126-167$

Cavanagh W., Mee C. 1998. A private place: death in prehistoric Greece. Studies in Mediterranean Archaeology vol. CXXV. Paul Åströms Förlag. Jonsered.

Cavanagh W., Crowel J., Catling R. W. V. and Shipley G. 2002. Continuity and Change in a Greek Rural Landscape: The Laconia Survey. Vol 1: Methodology and Interpretation. ABSA Supplement 26. British School at Athens. London.

Cavanagh W. G. 2004. WYSIWYG: Settlement and Territoriality in Southern Greece during the Early and Middle Neolithic periods. Journal of Mediterranean Archaeology 17(2): 165-189.
2007. Food preservation in Greece during the Late and Final Neolithic periods. In C. Mee, J. Renard (eds.), Cooking up the past. Food and culinary practices in the Neolithic and Bronze Age Aegean. Oxbow books, Oxford: 109-122.

Chapman J. 1991. The creation of social arenas in the Neolithic and Copper Age of SE Europe: the case of Varna. In P. Garwood, D. Jennings, R. Skeates and J. Toms (eds.), Sacred and profane. Proceedings of a conference on archaeology, ritual and religion, Oxford 1989. Oxford University Committee for Archaeology Monograph No. 32. Oxbow books, Oxford: 152-171.

1993. Social power in the Iron Gates Mesolithic. In J. Chapman and P. Dolukhanov (eds.), Cultural transformations and interactions in eastern Europe. Worldwide Archaeology Series 6. Avebury, Aldershot: 71-121.

1994. Social power in the early farming communities of eastern Hungary - Perspectives of the Upper Tisza region. A Jósa András Múseum Évkönyve XXXVI: 7999.

1997. Changing gender relations in the later prehistory of eastern Hungary. In J. Moore, E. Scott (eds.), Invisible people and processes. Writing gender and childhood into European prehistory. Leicester University Press, Leicester: 131-149.

2000. Pit-digging and structured deposition in the Neolithic and Copper Age. Proceedings of the Prehistoric Society 66: 61-87.

Coleman J. E. 1977. Keos I, Kephala: A Late Neolithic settlement and cemetery. The American School of Classical Studies at Athens. Princeton, New Jersey.

1992a. Greece, the Aegean and Cyprus. In R. W. Ehrich (ed.), Chronologies in Old World Archaeology. Chicago: 247-279.

1992b. Excavations at Halai, 1990-1991. Hesperia 61 (3): 265-289.

Dakoronia F., Kotoulas D., Balta E., Sythiakaki V. and Tolias G. 2002. Lokrida: Istoria kai Politismos. Ekdoseis Ktimatos Hatzimichali. Athens.

Darvill T. 1997. Neolithic Landscapes: Identity and Definition. In P. Topping (ed.), Neolithic Landscapes. Neolithic Studies Group Seminar Papers 2. Oxbow books, Oxford: 1-13.

Demoule J. P., Perlès C. 1993. The Greek Neolithic: a new review. Journal of World Prehistory 7(4): 355-416. 
Dousougli A. 1998. Aria Argolidos. I xeiropoiiti keramiki tis Neoteris Neolithikis kai Chalkolithikis periodou. Demosieumata tou Archaiologikou Deltiou 66. Athens.

Felsch R. C. S. 1988. Das Kastro Tigani. Die spätneolithische und chalkolithische Siedlung. Samos, Band 2. Bonn.

Felten F., Hiller S. 1996. Ausgrabungen in der vorgeschichtlichen Innenstadt von Ägina-Kolonna (Alt-Ägina). Sonderdruck aus den Jahresheften des Österreichischen Archäeologischen Institutes Band 65. Beiblatt: 29-112.

Goldmann H. 1940. The Acropolis of Halai. Hesperia 9: 381-514.

Hadjianastasiou 0. 1988. A Late Neolithic settlement at Grotta, Naxos. In E. B. French, K. A. Wardle (eds.), Problems in Greek Prehistory. Bristol Classical Press, Bristol: 11-20.

Halstead P. 1989. The economy has a normal surplus: economic stability and social change among early farming communities of Thessaly, Greece. In P. Halstead, J. O'Shea (eds.), Cultural responses to risk and uncertainty. New Directions in Archaeology. Cambridge University Press, Cambridge: 68-80.

1994. The North-South divide: regional paths to complexity in prehistoric Greece. In C. Mathers, S. Stoddart (eds.), Development and decline in the Mediterranean Bronze Age. Sheffield Archaeological Monographs 8. Sheffield Academic Press, Sheffield: 195-219.

1995. From sharing to hoarding: the Neolithic foundations of Aegean Bronze Age society. In R. Laffineur, W. D. Niemeier (eds.), Politeia: society and state in the Aegean Bronze Age. Proceedings of the $5^{\text {th }}$ International Aegean Conference, University of Heidelberg, Archäeologisches Institut, 10-13 April 1994. Aegaeum 12. Universitè de Liège, Histoire de l'art et archéologie de la Grèce antique, University of Texas at Austin, Liège and Austin: 11-21.

Hamilakis Y. 1998. Eating the dead: mortuary feasting and the politics of memory in the Aegean Bronze Age Societies. In K. Branigan (ed.), Cemetery and society in the Aegean Bronze Age. Sheffield studies in Aegean Archaeology 1. Sheffield Academic Press, Sheffield: 115-132.

Hatziaggelakis L. 1984. 0 proistorikos oikismos tis Petromagulas. Anthropologika 5: 75-85.

Hayden B. 2001. Fabulous feasts: a prolegomenon to the importance of feasting. In M. Dietler, B. Hayden (eds.), Feasts: archaeological and ethnographic perspectives on food, politics and power. Smithsonian Institution Press, Washington and London: 23-64.
Hodder I. 1990. The Domestication of Europe. Structure and Contingency in Neolithic Societies. Basic Blackwell. Oxford.

Howell R. J. 1992. Final Neolithic phase. In A. William, N. McDonald and C. Wilkie (eds.), Excavations at Nichoria in Southwest Greece: The Bronze Age Occupation, Vol. II. University of Minnesota Press, Minneapolis: 8-15.

Hutchinson R. W. 1935. Bothroi. The Journal of Hellenic Studies 55(1): 1-19.

Immerwahr S. A. 1971. The Athenian Agora: Results of Excavations conducted by the American School of Classical Studies at Athens, Volume XIII. The Neolithic and Bronze Ages. The American School of Classical Studies at Athens. Princeton, New Jersey.

1982. The earliest Athenian grave. In Studies in Athenian Architecture, Sculpture and Topography. Presented to Homer A. Thompson. Hesperia Supplements 20. The American School of Classical Studies at Athens. Princeton: 54-62.

Johnson M. 1999. Chronology of Greece and south-east Europe in the Final Neolithic and Early Bronze Age. Proceedings of the Prehistoric Society 65: 319-336.

Kakavogianni O., Dimitriou K., Koutsothanasis C. and Petrou A. 2009. Early Helladic settlement at Merenda. In V. Vassilopoulou, S. Katsarou-Tzeveleki (eds.), From Mesogeia to Argosaronikos. Second Ephorate of Prehistoric and Classical Antiquities. Research of a Decade, 19942003. Proceedings of the Conference held in Athens on December 18-20, 2003. Ministry of Culture and Municipality of Markopoulo of Mesogeia, Athens: 159-175.

Keller D. 1982. Final Neolithic pottery from Plakari, Karystos. In P. Spitaels (ed.), Studies in South Attica I. Miscellanea Graeca, fasc. 5. Belgian Archaeological Mission in Greece, Gent: 47-67.

Kontaxi C. 1996. B Kouveleiki spilia Alepochoriou. Archaeologikon Deltion, Chronika 51: 711-712.

Kopytoff I. 1986. The cultural biography of things: commodization as process. In A. Appadurai (ed.), The social life of things: commodities in cultural perspective. Cambridge University Press, Cambridge: 64-91.

Korres G. S. 1977. Ergasiai, ereunai kai anaskafai ana tin Pylian. Praktika tis en Athinais Arxaiologikis Etaireias: 229-235.

1978. Ereunai kai anaskafai ana tin Pylian. Praktika tis en Athinais Arxaiologikis Etaireias: 321-360. 
1979. Anaskafi Voidokoilias Pylias. Praktika tis en Athinais Arxaiologikis Etaireias: 138-155.

Kotsakis K. 1999. What tells can tell: social space and settlement in the Greek Neolithic. In P. Halstead (ed.), Neolithic society in Greece. Sheffield Studies in Aegean Archaeology 2. Sheffield Academic Press, Sheffield: 66-76.

Manos I. 2011. Les industries lithiques taillées du site de Proskynas, Grèce Centrale (Néolithique Récent/Bronze Ancien): Caractérisation et contexte regional. Unpublished $\mathrm{PhD}$ thesis. University of Montpellier III. France.

Manteli K. 1992. The Neolithic well at Kastelli Phournis in Eastern Crete. Annual of the British School at Athens 87: 103-120.

Nakou G. 1995. The cutting edge: a new look at early Aegean metallurgy. Journal of Mediterranean Archaeology 8(2): 1-32.

Nanoglou S. 2001. Social and monumental space in Neolithic Thessaly, Greece. European Journal of Archaeo$\log$ 4(3): 303-322.

2008. Building biographies and households. Aspects of community life in Neolithic Northern Greece. Journal of Social Archaeology 8(1): 139-160.

Nazou M. 2010. Grey Areas in Past Maritime Identity? The case of Final Neolithic - Early Bronze Age Attica (Greece) and the surrounding islands. Shima: The International Journal of Research into Island Cultures 4(1): 3-15.

Nowicki K. 2008. The Final Neolithic (Late Chalcolithic) to Early Bronze Age Transition in Crete and the Southeast Aegean Islands: Changes in Settlement Patterns and Pottery. In V. Isaakidou, P. Tomkins (eds.), Escaping the Labyrinth. The Cretan Neolithic in Context. Oxbow Books, Oxford: 200-228.

Pantelidou-Gofas M. 2008. The deposit pit at Tsepi, Marathon: features, formation and the breakage of the finds. In N. Brodie, J. Doole, G. Gavalas and C. Renfrew (eds.), Horizon: a colloquium on the prehistory of the Cyclades. Cambridge 25-28 March 2004. McDonald Institute for Archaeological Research, Cambridge: 281-289.

Papathanasiou A. 2001. A bioarchaeological analysis of Neolithic Alepotrypa cave, Greece. BAR IS 961. Archaeopress. Oxford.

2009. Mortuary behavior in Alepotrypa Cave: assessments from the study of the human osteological material. In W. G. Cavanagh, C. Gallou and M. Georgiadis (eds.), Sparta and Laconia: From Prehistory to Premodern. Proceedings of the Conference held in Sparta, organised by the British School at Athens, the Univer- sity of Nottingham, the $5^{\text {th }}$ Ephoreia of Prehistoric and Classical Antiquities and the $5^{\text {th }}$ Ephoreia of Byzantine Antiquities, 17-20 March 2005. British School at Athens Studies 16. British School at Athens, London: 21-28.

Papathanasopoulos G. A. 1971. Spilaia Dirou, 1971. Archaiologika Analekta ex Athenon 4(3): 289-304.

1996a. Neolithic Culture in Greece. Nicholas P. Goulandris Foundation, Museum of Cycladic Art. Athens.

1996b. Burial customs at Diros. In G. A. Papathanasopoulos (ed.), Neolithic Culture in Greece. Nicholas P. Goulandris Foundation, Museum of Cycladic Art, Athens: $175-177$.

Pappa M., Halstead P., Kotsakis K. and Urem-Kotsou D. 2004. Evidence for large-scale feasting at Late Neolithic Makriyalos, northern Greece. In P. Halstead, J. C. Barrett (eds.), Food, cuisine and society in prehistoric Greece. Sheffield Studies in Aegean Archaeology 5. Oxbow books, Oxford: 16-44.

Pappa M. 2008. Organosi tou Horou kai Koinotika Stoicheia stous Neolithikous Oikismous tis Kedrikis Makedonias. Unpublished PhD thesis. Aristotle University of Thessaloniki. Thessaloniki.

Parker Pearson M. 1993. The powerful dead: archaeological relationships between the living and the dead. Cambridge Archaeological Journal 3(2): 203-229.

Perlès C. 1992. Systems of exchange and organization of production in Neolithic Greece. Journal of Mediterranean Archaeology 5: 115-164.

Phelps W. W. 1975. The Neolithic pottery sequence in southern Greece. Unpublished PhD thesis. University of London. London.

2004. The Neolithic pottery sequence in southern Greece. BAR IS 259. Archaeopress. Oxford.

Protonotariou-Deilaki E. 1971. Anaskafi Nauplias. Archaiologika Analekta ex Athenon 4(1): 10-11.

Psimogiannou A. 2008. I neolithiki egkatastasi ston Proskyna Phthiotidos. Unpublished MA thesis. Aristotle University of Thessaloniki. Thessaloniki.

Pullen D. J. 1990. The Early Bronze Age village on Tsoungiza Hill, ancient Nemea. In P. Darque, R. Treuil (eds.), $L^{\prime}$ habitat Égéen Préhistorique, Actes de la Table Ronde internationale organisée par le Centre National de la Recherche Scientifique, l' Université de Paris I et l' École française de' Athènes (Athènes, 23-25 Juin 1987). Bulletin de Correspondence Hellénique Supplément XIX. ADPF-École Française d' Athènes. Paris: 331-346. 
2000. The prehistoric remains of the acropolis at $\mathrm{Ha}$ lieis: a final report. Hesperia 69(2): 133-187.

2011. The Early Bronze Age Village on Tsoungiza Hill. Nemea Valley Archaeological Project 1. The American School of Classical Studies at Athens. Princeton, New Jersey.

Pylarinou D., Vasilakis A. 2010. Excavation of FN/Early Prepalatial settlement at Gazi. In M. Andrianakis and I. Tzachili (eds.), Archaeological Work in Crete 1: Proceedings of the First Meeting, Rethymnon, 28-30 November 2008. University of Crete, Rethymnon: 276-284.

Renfrew C. 1972. The emergence of civilization. The Cyclades and the Aegean in the third millennium B.C. Methuen. London.

Richards C. C., Thomas J. S. 1984. Ritual activity and structured deposition in later Neolithic Wessex. In R. Bradley, J. Gardiner (eds.), Neolithic Studies. BAR BS 133. Oxford: 189-218.

Rowlands M. 1993. The role of memory in the transmission of culture. World Archaeology 25(2): 141-151.

Runnels C. N., van Andel T. H. 1987. The evolution of settlement in the southern Argolid, Greece: an economic explanation. Hesperia 56(3): 303-334.

Runnels C., Pullen D. and Langdon S. 1995. Artifact and assemblage. The finds from a regional survey of the southern Argolid, Greece, Volume I. The Prehistoric and Early Iron Age pottery and the lithic artifacts. Stanford University Press. Stanford, California.

Sampson A. 1993. Skoteini Tharrounion. To spilaio, o oikismos kai to nekrotafeio. Athens.

Skourtopoulou K. 2006. Questioning Spatial Contexts: The Contribution of Lithics Studies as Analytical and Interpretative Bodies of Data. In D. Papakonstantinou (ed.), De-constructing Context. Oxbow books, Oxford: 50-78.

Sofaer R. J. 2006. The Body as Material Culture. A Theoretical Osteoarchaeology. Cambridge University Press. Cambridge.

Spitaels P. 1982. Final Neolithic pottery from Thorikos. In P. Spitaels (ed.), Studies in South Attica I. Miscellanea Graeca, fasc. 5. Belgian Archaeological Mission in Greece, Gent: 9-44.

Steinhauer G. 2001. Two Neolithic settlements. In S. A. Idea and K. Tsouni (eds.), Mesogaia: history and culture of Mesogeia in Attica. Athens International Airport S.A. 'Eleftherios Venizelos', Athens: 28-34.
Tasić N. N., Tasić N. 2003. Serbian Prehistoric Archaeology in the 1990s. State of Research. In D.V. Grammenos (ed.), Recent Research in the Prehistory of the Balkans. Publications of the Archaeological Institute of Northern Greece, Nr. 3, Thessaloniki: 72-128.

Televantou Ch. 2008. A Neolithic settlement on Andros. In N. Brodie, J. Doole, G. Gavalas and C. Renfrew (eds.), Horizon: a colloquium on the prehistory of the Cyclades, Cambridge, 25-28 March 2004. McDonalt Institute for Archaeological Research, Cambridge: 43-53.

Todaro S., Di Tonto S. 2008. The Neolithic Settlement of Phaistos Revisited: Evidence for Ceremonial Activity on the Eve of the Bronze Age. In V. Isaakidou and P. Tomkins (eds.), Escaping the Labyrinth. The Cretan Neolithic in Context. Oxbow Books, Oxford: 176-190.

Tomkins P. 2004. Filling in the 'Neolithic Background': Social Life and Social Transformation in the Aegean Before the Bronze Age. In J. C. Barrett and P. Halstead (eds.), The Emergence of Civilization Revisited. Oxbow books, Oxford: 38-63.

2007. Communality and competition: the social life of food and containers at Aceramic and Early Neolithic Knossos, Crete. In C. Mee and J. Renard (eds.), Cooking up the past. Food and culinary practices in the Neolithic and Bronze Age Aegean. Oxbow books, Oxford: 174-199.

2008. Time, Space and Reinvention of the Cretan Neolithic. In V. Isaakidou and P. Tomkins (eds.), Escaping the Labyrinth. The Cretan Neolithic in Context. Oxbow Books, Oxford: 21-48.

2009. Domesticity by default. Ritual, Ritualization and Cave-use in the Neolithic Aegean. Oxford Journal of Archaeology 28(2): 125-153.

Touchais G. 1980. La céramique néolithique de l' Aspis. In Études Argiennes. Bulletin de Correspondence Hellénique Supplément VI: 1-40.

Toufexis G. 1997. Recent Neolithic Research in the Eastern Thessalian plain, Greece: a Preliminary Report. In H. Erkanal, H. Hauptmann, V. Şahoğlu and R. Tuncel (eds.), The Aegean in the Neolithic, Chalcolithic and the Early Bronze Age. Proceedings of the International Symposium, October $13^{\text {th }}-19^{\text {th }} 1997$, Urla-Izmir (Turkey). Ankara University, Ankara: 569-579.

Tsota E. 2009. Eurimata tis Telikis Neolithikis kai PE I periodou apo tin anaskafi tis anisopedis diavasis OSE sti Thiva. In A. Mazarakis Ainian (ed.), Archaeological Work on Thessaly and Central Greece, 2. Volos 16.3 - 19.3. 2006, Greece. University of Thessaly \& Greek Ministry of Culture, Volos: 855-872. 
Urem-Kotsou D., Kotsakis K. 2007. Pottery, cuisine and community in the Neolithic of north Greece. In C. Mee and J. Renard (eds.), Cooking up the past. Food and culinary practices in the Neolithic and Bronze Age Aegean. Oxbow books, Oxford: 225-246.

van Andel T. H., Runnels C. N. and Pope K. O. 1986. Five thousand years of land use and abuse in the southern Argolid, Greece. Hesperia 55(1): 103-128.

van Andel T. H., Runnels C. N. 1988. An essay on 'the emergence of civilization' in the Aegean world. Antiquity 62: $234-247$.

Van de Moortel A., Zahou E. 2006. 2004 Excavations at Mitrou, east Lokris. Aegean Archaeology 7: 39-48.

Veropoulidou R. 2011. Spondylus gaederopus Tools and Meals in Central Greece from the $3^{\text {rd }}$ to the Early $1^{\text {st }}$ Millennium B.C. In F. Ifantidis, M. Nikolaidou (eds.), Spondylus in Prehistory. New data and approaches. Contributions to the archaeology of shell technologies. Archaeopress, Oxford: 191-208.

Vitelli K. D. 1995. Pots, potters and the shaping of Greek Neolithic. In W. K. Barnett and J. W. Hoopes (eds.), The emergence of pottery: technology and innovation in ancient societies. Smithsonian Institution Press, Washington: 55-63.

1999. Franchthi Neolithic Pottery 2: the later Neolithic ceramic phases 3 to 5. Excavations at Franchthi cave, Greece: fascicle 10. Indiana University Press. Bloomington, Indiana.

2007. Lerna. A Preclassical site in the Argolid, Volume $V$. The Neolithic pottery from Lerna. The American School of Classical Studies at Athens. Princeton.

Wace A. J. B., Thompson M. S. 1912. Prehistoric Thessaly. Cambridge University Press. Cambridge.

Wace A. J. B., Blegen C. W. 1916-18. The Pre-Mycenaean Pottery of the Mainland. British School Annual XXII: 175-189.

Watrous L. V. 1994. Review of Aegean Prehistory III: Crete from earliest prehistory through the protopalatial period. American Journal of Archaeology 98(4): 695753.

Weinberg S. S. 1962. Excavations at prehistoric Elateia, 1959. Hesperia 31: 158-209.

Wells B., Runnels C. and Zangger E. 1990. The BerbatiLimnes archaeological survey: the 1988 season. Opuscula Atheniensia XVIII(15): 207-238.
Williams H. 1998. Monuments and the past in early AngloSaxon England. World Archaeology 30(1): 90-108.

Wilson D. E. 1999. Keos IX. Ayia Irini Periods I-III. The Neolithic and Early Bronze Age Settlements. Part I: The Pottery and Small Finds. Philipp von Zabern. Mainz on Rhine.

Wright J. C. 2004. The Emergence of Leadership and the Rise of Civilization in the Aegean. In J.C. Barrett and P. Halstead (eds.), The Emergence of Civilization Revisited. Oxbow books, Oxford: 64-89.

Zachos K. L. 1987. Ayios Dhimitrios. A prehistoric settlement in the southwestern Peloponnesos: the Neolithic and Early Helladic Periods. Unpublished PhD thesis. Boston University. University Microfilms. Ann Arbor.

1999. Zas cave on Naxos and the role of caves in the Aegean Late Neolithic. In P. Halstead (ed.), Neolithic society in Greece. Sheffield studies in Aegean Archaeology 2. Sheffield Academic Press, Sheffield: 153-163.

Zahou E. 2002. The development of the material culture through the Neolithic to Early Bronze Age as it appeared in northern Phthiotis. Paper presented at the $8^{\text {th }} \mathrm{EAA}$ Annual Meeting, 24-29 September 2002, Thessaloniki, Greece.

2004. Die Frühbronzezeithliche Siedlung in Proskynas, Lokris. In E. Alram-Stern (ed.), Die Ägäishe Frühzeit, 2. Serie Forschungsbericht 1975-2002, 2. Band Die Frühbronzezeit in Griechenland mit Ausnahme von Kreta und Zypern. Verlag der Österreichischen Academie der Wissenschaften, Wien: 1267-1284.

2009. O protoelladikos oikismos tou Proskyna. I organosi tou horou, i paragogi kai i katanalosi tis keramikis. Unpublished PhD thesis. Aristotle University of Thessaloniki. Thessaloniki.

Zahou E., Psimogiannou K. forthcoming. I dimiourgia topon sto lofo tou Proskyna: i apeikonisi tis anthropinis drasis sto horo kai sto hrono. Paper presented at the $4^{\text {th }} \mathrm{Ar}$ chaeological Work on Thessaly and Central Greece, Volos 15.3 - 18.3.2012, Greece.

Zapheiropoulou Ph. 2008. Early Bronze Age cemeteries of the Campos group on Ano Kouphonisi. In N. Brodie, J. Doole, G. Gavalas and C. Renfrew (eds.), Horizon: a colloquium on the prehistory of the Cyclades. Cambridge 25-28 March 2004. McDonald Institute for Archaeological Research, Cambridge: 183-194. 